\title{
Effects of $\beta$-Glucans from Aureobasidium pullulans on Cucumber Mosaic Virus Infection in Chili Pepper
}

\author{
*Corresponding author \\ Tel: +82-63-238-0752 \\ Fax: +82-63-238-6305 \\ E-mail: viroid73@gmail.com \\ ORCID \\ https://orcid.org/0000-0002-0546-3755 \\ 'These authors contributed equally to \\ this work.
}

Received November 10, 2020

Revised January 2, 2021

Accepted January 5, 2021

\author{
Ju-Yeon Yoon ${ }^{1 \dagger}$, V. S. R. Gangireddygari ${ }^{1 \dagger}$, In-Sook Cho ${ }^{1}$, Bong-Nam Chung ${ }^{1}$, \\ Byung-Dae Yoon ${ }^{2}$, and Seung-Kook Choi ${ }^{3^{*}}$ (D) \\ ${ }^{1}$ Horticultural and Herbal Crop Environment Division, National Institute of Horticultural and Herbal \\ Science, Rural Development Administration, Wanju 55365, Korea \\ ${ }^{2}$ HD Bio-Corporation, KRIBB-BVC, Daejeon 34141, Korea \\ ${ }^{3}$ Division of Research Planning and Coordination, Rural Development Administration, Jeonju 54875, \\ Korea
}

Cucumber mosaic virus (CMV), the most prevalent virus in chili pepper (Capsicum annuum L.), negatively affects chili pepper production in South Korea. In this study, foliar spraying with $\beta$-glucans obtained from the mycelial walls of the yeast-like fungus Aureobasidium pullulans inhibited CMV infection of chili pepper if applied before virus inoculation. At three concentrations, $\beta$-glucans from A. pullulans significantly ameliorated CMV symptoms in treated chili pepper; the effect was greater in plants treated with $0.01 \% \beta$-glucans than $0.005 \%$ or $0.001 \% \beta$-glucans. Double antibody sandwich enzyme-linked immunosorbent assay showed that these $\beta$-glucans treatments resulted in 1.7- to 10-fold reductions in CMV accumulation in the treated chili pepper. The glucans did not act directly on the virus and did not interfere with virus disassembly or replication. Foliar spraying with $0.01 \% \beta$-glucans from A. pullulans at $24 \mathrm{hr}$ intervals for 3 days significantly increased plant height, the total number of fruit, and the fresh weight of chili pepper fruit. However, the stem diameter of chili pepper treated with $\beta$-glucans did not increase significantly. These results indicate that foliar spraying with $\beta$-glucans from $A$. pullulans acts an antiviral agent against CMV infection and stimulates chili pepper growth.

Keywords: Antiviral activity, $\beta$-glucans, Chili pepper, Cucumber mosaic virus (CMV), Pepper growth

\section{Introduction}

Chili pepper (Capsicum annuum L.) is a very important vegetable. In South Korea, it is used in Kimchi and as seasoning for food. In 2019, 31,640 ha were cultivated in South Korea and more than 78,000 tons of chili pepper were produced (Statistics Korea, 2019). Of the viruses that infect chili pepper, cucumber mosaic virus (CMV; genus Cucumovirus, family Bromoviridae) was first reported in cucumber (Cucumis sa-

Research in Plant Disease

pISSN 1598-2262, elSSN 2233-9191

www.online-rpd.org tivus L.) independently by three scientists in 1916 (Doolittle, 1916; Gilbert, 1916; Jagger, 1916). CMV is one of the top 10 most studied viruses (Scholthof et al., 2011). It has one of the largest host ranges of any plant virus, infecting 1,071 species in 521 genera from 100 families (Yoon et al., 2019). CMV is the most prevalent virus in chili pepper in South Korea (Cho et al., 2007; Choi et al., 2005; Kwon et al., 2018; Lee et al., 2015). In nature, it is efficiently transmitted by more than 80 aphid species in a nonpersistent manner and through seeds in many plant species (Fereres and Perry, 2019). CMV can be artificially transmitted to new plant species using mechanical inoculation. CMV is multi-component single stranded virus, with three positive-sense RNA's (RNA1, RNA2, and RNA3) and 
an additional subgenomic RNA (RNA4) derived from RNA3 (Habili and Francki, 1974; Peden and Symons, 1973). RNA2 codes for the 2a protein, which is an RNA-dependent RNA polymerase of replication complex, whereas, RNA 1 codes for the 1a protein, another subunit of CMV replicase complex (Hayes and Buck, 1990). RNA3 encodes for two proteins involved in viral movement and encapsidation (Canto et al., 1997; Kaplan et al., 1997).

In several genetic studies, CMV resistances conferred by dominant $\mathrm{R}$ genes encoding nucleotide-binding and leucine-rich repeat class immune receptors were described from Arabidopsis, common bean, and melon (Giner et al., 2017; Kang et al., 2010; Sekine et al., 2008; Seo et al., 2006; Takahashi et al., 2002). In pepper, various resistance types conferred by $\mathrm{R}$ genes and recessive genes were described in C. annuum 'Perennial' (Caranta and Palloix, 1996; Grube et al., 2000; Lapidot et al., 1997), C. annuum 'Lam32' (Choi et al., 2018), C. annuum Vania' (Caranta et al., 2002), C. annuum 'Sapporo-oonaga' and 'Nanbu-oonaga' (Suzuki et al., 2003), C. frutescens 'BG2814-6' (Grube et al., 2000), C. frutescens 'LS1839-2-4', and C. baccatum 'PI439381-1-3' (Kang et al., 2010; Suzuki et al., 2003).

Because genes that confer resistance to $\mathrm{CMV}$ are present in very few crops, it takes a long time to develop resistant commercial pepper cultivars. In experiments, a chili pepper carrying the $\mathrm{Cmr1}$ resistance gene was highly resistant to a Korean strain of CMV and the Fny strain of CMV (Kang et al., 2010). However, CMV-P1 strains that belong to CMV subgroup IB can overcome CMV resistance in pepper cultivars carrying the $\mathrm{Cmr} 1$ gene (Lee et al., 2006). Surveys for CMV isolates in cultivated chili pepper plants found the highest frequency of CMV-P1 strains in CMV isolates collected from chili pepper plants, and the CMV-P1 population in chili pepper in South Korea was extensive (Cho et al., 2007; Kwon et al., 2018; Lee et al., 2015). Recently, a new resistance gene (named cmr2 gene) was identified for $\mathrm{CMV}$ resistance in a recessive manner (Choi et al., 2018). However the resistance source is not introduced into commercial pepper inbred lines yet and it remains to be detail characterization of gene identification and its functions in pepper cells. Apart from $\mathrm{R}$ genes or recessive genes, natural compounds from pathogenic or saprophytic bacteria and fungi or their byproducts have shown potential to control CMV disease without reducing plant growth (Choi et al., 2014; Lee and Ryu, 2016; Song et al., 2013).

Observation in plant systems that polysaccharides from microorganism including fungi or from algae play a crucial role in enhancement of plant defense responses against viruses. Of the biologically active polysaccharides, $\beta$-glucans from Phytophthora megasperma f. sp. glycinea and $\beta$-glucans from brown algae showed efficient elicitors of defense responses in different plant species, such as $\mathrm{H}_{2} \mathrm{O}_{2}$ production, salicylic acid accumulation, and pathogenesis-related gene induction, in different plant species (Aziz et al., 2003; Klarzynski et al., 2000; Ménard et al., 2004).

In this study, we evaluated the potential of foliar application of $\beta$-glucans $(\beta-[1 \rightarrow 3]$, $[1 \rightarrow 6]$-D-glucans) from Aureobasidium pullulans, a ubiquitous black yeast-like fungus, for managing CMV disease in chili pepper in South Korea under greenhouse conditions.

\section{Materials and Methods}

Virus source. The CMV strain GTN (CMV-GTN) used in this study was originally obtained from the chili pepper cultivar Cheongyang (Choi et al., 2015). The strain induces mosaic symptoms and top necrosis in all chili pepper cultivars. CMVGTN was maintained in Nicotiana tabacum cv. Xanthi nc.

Preparation of $\boldsymbol{A}$. pullulans $\boldsymbol{\beta}$-glucans. A. pullulans culture fluid was prepared as described previously (Muramatsu et al., 2017). Briefly, A. pullulans was grown at $25^{\circ} \mathrm{C}$ for 10 days in medium containing $2.0 \%$ sucrose, $0.3 \%$ powdered rice bran, $0.08 \%$ sodium L-ascorbate, and $0.02 \%$ L-ascorbic acid. Then the culture medium was heated at $90^{\circ} \mathrm{C}$ for 30 min and diluted with $1 \times$ phosphate buffered saline to 2 $\mathrm{mg} / \mathrm{ml} \beta$-glucans $(\beta-[1 \rightarrow 3],[1 \rightarrow 6]-D-g l u c a n s)$. The purified $\beta$-glucans from $A$. pullulans was prepared with powdered activated carbon, ultrafiltration with a cutoff molecular weight of 20,000, and ethanol precipitation as described previously (Muramatsu et al., 2017).

Treatment with $A$. pullulans $\boldsymbol{\beta}$-glucans and virus inoculation. Leaves of 4-leaf-stage chili pepper plants (cv. Cheongyang, 20 plants per treatment) were sprayed with different concentrations $(0.001 \%, 0.005 \%$, or $0.01 \%)$ of $\beta$-glucans or sterile distilled water as a control at $24 \mathrm{hr}$ intervals for 3 days, respectively. One day after the final spraying (afs), the cotyledons of the chili pepper plants were inoculated mechanically with sap from tobacco infected with CMV-GTN or sterile distilled water as a control. The inoculated plants were 
maintained in a greenhouse, and symptoms were evaluated for 5 weeks from 14 days post-inoculation (dpi) for analyses of CMV infection. All experiments were performed in triplicate, and data are presented as means \pm standard deviations.

To examine the effect of $\beta$-glucans on pepper growth, we planted 80 young chili pepper plants (cv. Cheongyang) at 40 $\mathrm{m}$ intervals in two rows. The leaves of 40 chili pepper plants were sprayed with $0.01 \% \beta$-glucans at $24 \mathrm{hr}$ intervals for 3 days or the leaves of 40 chili pepper plants were sprayed with sterile distilled water as a control at $24 \mathrm{~h}$ intervals for 3 days. Plant height, stem diameter, fruit number, and fruit weight of the all chili pepper plants were observed from 1 to 8 weeks afs. All experiments were performed in triplicate, and data are presented as means \pm standard deviations.

\section{Double antibody sandwich enzyme-linked immuno-} sorbent assay. CMV was detected with a double antibody sandwich enzyme-linked immunosorbent assay (DAS-ELISA) kit according to the manufacturer's protocol (Agdia, Elkhart, IN, USA). Briefly, the plant tissue extract was prepared by powdering about $0.1 \mathrm{~g}$ chili pepper leaves at $14 \mathrm{dpi}$ in liquid nitrogen with a mortar and pestle and ground with $1 \mathrm{ml}$ standard extraction buffer (SEB1) supplied by the manufacturer protocol (Agdia). After a brief centrifugation, 100 $\mu \mathrm{l}$ of upper clean supernatant of leaf samples, positive and negative controls were added to an anti-CMV-coated 96- well plate and incubated for $2 \mathrm{hr}$ at room temperature. After washing, the plates were incubated with alkaline phosphatase-conjugated enzyme for $4 \mathrm{hr}$. Substrate ( $p$-nitrophenyl phosphate) at $1 \mathrm{mg} / \mathrm{ml}$ was added and incubated at room temperature. The plates were read with an automated plate reader (Titertek, Huntsville, AL, USA) at $405 \mathrm{~nm}$. A sample was considered positive if the optical density exceeded 3 times the mean of the negative controls (Yoon et al., 2011).

Data analyses. The data were assessed with analysis of variance (ANOVA) with SigmaPlot ver. 11 (Systat Software, San Jose, CA, USA). Differences among the $\beta$-glucans treatments were determined with Duncan's multiple range test with significance set at $P<0.05$.

\section{Results}

To determine whether $\beta$-glucans from A. pullulans reduces the severity of CMV symptoms in chili pepper plants, we assessed its ability to protect chili pepper against CMV under greenhouse conditions. Three different concentrations of $\beta$-glucans significantly ameliorated CMV symptoms in treated chili pepper plants at $14 \mathrm{dpi}$ (Fig. 1); the effect of symptom amelioration was observed until 5 weeks post-inoculation, showing that the effect was greater for $0.01 \% \beta$-glucans than $0.005 \%$ or $0.001 \% \beta$-glucans. These $\beta$-glucans treatments

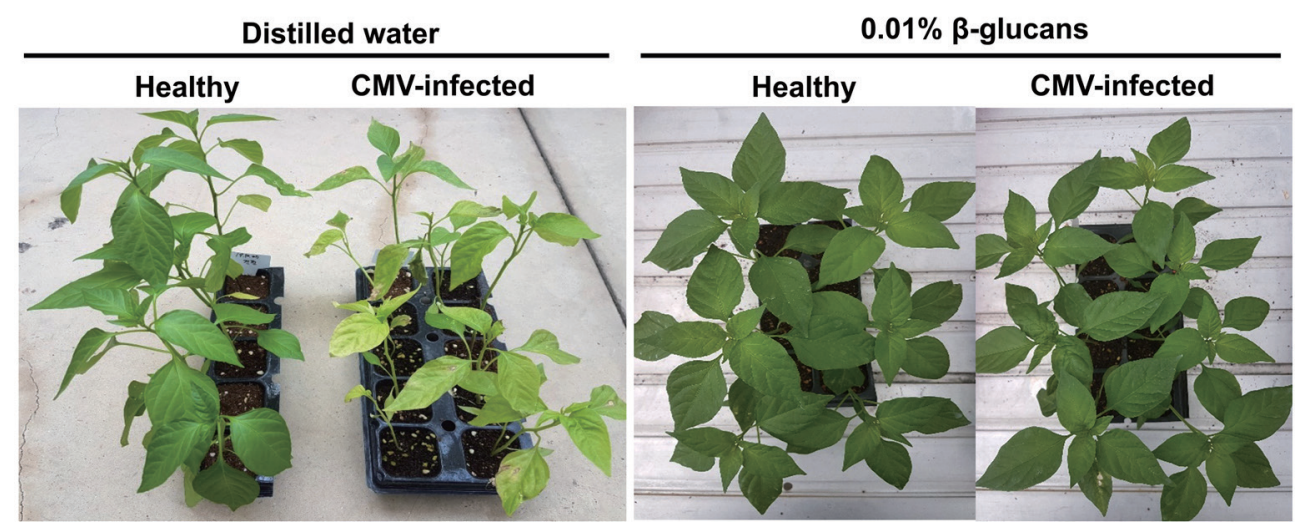

Fig. 1. Effects of $\beta$-glucans from Aureobasidium pullulans on chili pepper plants infected with cucumber mosaic virus (CMV) strain GTN. Leaves of 4-leaf-stage chili pepper plants (cv. Cheongyang, 20 plants per treatment) were sprayed with different concentrations (0.001\%, $0.005 \%$, or $0.01 \%$ ) of $\beta$-glucans or sterile distilled water as a control at $24 \mathrm{hr}$ intervals for 3 days, respectively. One day after the final spraying, the cotyledons of the chili pepper plants were inoculated mechanically with sap from tobacco infected with CMV-GTN or sterile distilled water as a control. The inoculated plants were maintained in a greenhouse, and symptoms were evaluated for 5 weeks from 14 days postinoculation (dpi) for analyses of CMV infection. All experiments were performed in triplicate, and data are presented as means \pm standard deviations. Representative images of chili pepper plants sprayed with $0.01 \%$ A. pullulans $\beta$-glucans at 14 dpi or chili pepper plants treated with distilled water (control) at $14 \mathrm{dpi}$ are shown. 


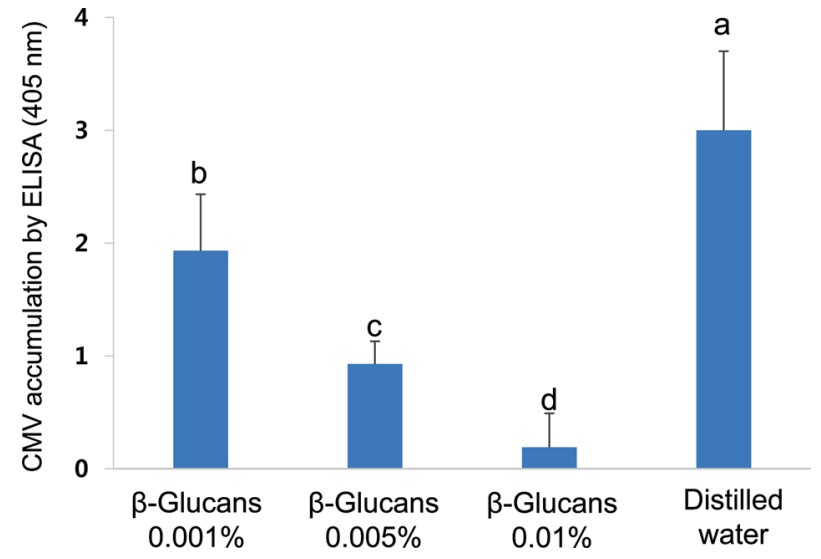

Fig. 2. Double antibody sandwich enzyme-linked immunosorbent assay (DAS-ELISA) results for cucumber mosaic virus (CMV) accumulation in chili pepper plants sprayed with three different concentrations of $\beta$-glucans from Aureobasidium pullulans. Primary detection of CMV was performed with DAS-ELISA kits (Agdia, Elkhart, IN, USA) according to the manufacturer's protocol. The plates were read with an automated plate reader (Titertek, Huntsville, AL, USA) at $405 \mathrm{~nm}$. A sample was considered positive if the optical density exceeded 3 times the mean of the negative controls. DAS-ELISA data were analyzed with analysis of variance. Differences among the mean values of $\beta$-glucans were determined with Duncan's multiple range test with significance set at $P<0.05$.

resulted in 1.7- to 10-fold reductions in CMV accumulation as quantified by DAS-ELISA compared to the distilled water control (Fig. 2). Therefore, foliar spraying with $\beta$-glucans from A. pullulans protects chili pepper plants against $C M V$ infection.

To test whether $\beta$-glucans from A. pullulans can cure CMV infection, we treated chili pepper plants infected systemically with CMV with $0.001 \%, 0.005 \%$, or $0.01 \% \beta$-glucans or sterile distilled water every day for 7 days. The DAS-ELISA results obtained from the treated leaf samples collected at 3 days afs showed no significant differences between the $\beta$-glucans treatments and control (data not shown), which suggests that $\beta$-glucans from A. pullulans cannot cure CMV in chili pepper.
We found that the chili pepper plants treated with $\beta$-glucans grew better. To assess the growth of chili pepper treated with $\beta$-glucans from A. pullulans, we planted plants in a greenhouse in the same manner as farmers grow them. The leaves were sprayed with $0.01 \% \beta$-glucans or sterile distilled water at $24 \mathrm{hr}$ intervals for 3 days. The chili pepper treated with $\beta$-glucans averaged $1.83 \mathrm{~cm}$ taller than the water-treated control 1 week afs. Then 6 weeks afs, the average height of the treated chili pepper was significantly greater than that of the control (Table 1). The effect on plant height could be seen until the end of the observations. The stem diameter was not affected by the $0.01 \% \beta$-glucans treatment, although the stem diameter of the treated chili pepper was slightly greater than that of the control (Table 1). In terms of yield, the total number of fruit on treated chili pepper plants planted in a $1,000 \mathrm{~m}^{2}$ greenhouse $(26,204$ fruit) was greater than that on the water control $(25,361$ fruit) 8 weeks afs. The increased number of fruit resulted in a greater fresh weight of pepper fruit than the controls. The average weight $(8.0 \mathrm{~g})$ and number $(n=54)$ of fruit per chili pepper treated with $\beta$-glucans were significantly greater than in the controls (Table 2). These results suggest that $\beta$-glucans from A. pullulans enhances the growth and yield of chili pepper.

\section{Discussion}

Although $\beta$-glucans from A. pullulans prevented CMV infection in chili pepper, it could not cure established CMV infections. The inhibitory effects of the $\beta$-glucans treatment decreased significantly as CMV infection developed (data not shown). This suggests that the timing of $\beta$-glucans spraying and the plant development stage are important for preventing CMV infection in chili pepper.

It has been demonstrated that $\beta$-glucans from the cell walls of phytopathogenic oomycetes of the genera Phytophthora

Table 1. Effects of $\beta$-glucans on plant height and stem diameter of chili pepper

\begin{tabular}{ccccc}
\hline & \multicolumn{2}{c}{ Distilled water } & \multicolumn{2}{c}{$\mathbf{0 . 0 1 \% ~} \boldsymbol{\beta}$-glucans $^{\mathrm{a}}$} \\
\cline { 2 - 5 } & Plant height $(\mathbf{c m})$ & Stem diameter $(\mathbf{m m})$ & Plant height $(\mathbf{c m})$ & Stem diameter $(\mathbf{m m})$ \\
\hline 1 week & $20.92 \pm 2.47 \mathrm{~b}$ & $18.21 \pm 0.38 \mathrm{~b}$ & $22.75 \pm 2.72 \mathrm{a}$ & $18.14 \pm 0.47 \mathrm{a}$ \\
3 weeks & $32.84 \pm 3.75 \mathrm{~b}$ & $19.51 \pm 0.57 \mathrm{~b}$ & $36.84 \pm 4.76 \mathrm{a}$ & $19.74 \pm 0.58 \mathrm{a}$ \\
6 weeks & $70.42 \pm 6.48 \mathrm{~b}$ & $25.54 \pm 1.01 \mathrm{~b}$ & $75.07 \pm 5.60 \mathrm{a}$ & $26.42 \pm 0.96 \mathrm{a}$ \\
\hline
\end{tabular}

${ }^{a}$ Pepper fruit was analyzed on 8 weeks after treatment of $0.01 \% \beta$-glucans or distilled water and differences among the $\beta$-glucans or distilled water treatments were determined with Duncan's multiple range test with significance set at $P<0.05$. 
Table 2. Effects of $\beta$-glucans on fruit weight and total number of fruit of chili pepper

\begin{tabular}{ccccc}
\hline \multirow{2}{*}{ Treatment } & \multicolumn{2}{c}{ Yield per $\mathbf{1 0}^{\text {a }}$} & \multicolumn{2}{c}{ Yield per plant } \\
\cline { 2 - 5 } & Fruit weight $\mathbf{( k g )})^{\mathbf{a}}$ & Total no. of fruits & Fruit weight (g) & Average fruit number \\
\hline Distilled water & 180 & 25,361 & 7.1 & 45.29 \\
$0.01 \%$-glucans & 211 & 26,204 & 8.02 & 54.58 \\
\hline
\end{tabular}

${ }^{a}$ Pepper fruit was harvested on 8 weeks after treatment of $0.01 \% \beta$-glucans or distilled water and differences among the $\beta$-glucans or distilled water treatments were determined with Duncan's multiple range test with significance set at $P<0.05$.

and Pythium is sufficient to elicit phytoalexin production in plants (Albersheim and Valent, 1978; Ayers et al., 1976; Ebel et al., 1976; Sharp et al., 1984a, 1984b). Similar to the current results, $1 \mathrm{mg} / \mathrm{ml}$ laminarin ( $\beta$-glucans from Laminaria cichoriodes) significantly inhibits tobacco mosaic virus (TMV) infection in N. tabacum cv. Xanthi nc (Reunov et al., 1996). Native $\beta$-glucans inhibits TMV infection, whereas sulfated laminarin inhibits both TMV infection and TMV replication (Ménard et al., 2005). These differences are likely due to the different origins and ratios of $\beta$-glucans or different plant species receptors (Fesel and Zuccaro, 2016).

The protective effects of $\beta$-glucans from A. pullulans on chili pepper can be explained only by the elicitation of plant innate immunity, because there are no reports on the direct inhibition of a plant virus by algae or their metabolites. These conclusions are supported by the fact that purified CMV particles and CMV genomic RNA were not degraded by the addition of $0.01 \% \beta$-glucans (data not shown). The protective effects of a glucan preparation from Phytophthora megasperma are not due to direct inactivation of TMV or to the binding of glucan or other components in the glucan preparation to TMV in a manner that can prevented stripping of the TMV coat protein and thereby reduce infectivity (Kopp et al., 1989). Laminarin and $\beta$-glucans of different origins elicit a wide range of defense responses, such as $\mathrm{H}_{2} \mathrm{O}_{2}$ production, salicylic acid (SA) accumulation, and pathogenesis-related gene induction, in different plant species (Aziz et al., 2003; Klarzynski et al., 2000; Ménard et al., 2004). Chemical elicitors, such as SA, can manage viral diseases in many crops, but these chemicals result in a growth penalty called the fitness cost (Heil and Baldwin, 2002). $\beta$-glucans from A. pullulans significantly improved the vegetative growth of chili pepper in this study (Table 1). Furthermore, the average weight and number of peppers increased substantially, which suggests the beneficial effects of $\beta$-glucans from A. pullulans on CMV protection and yield in chili pepper. SA enhances fruit weight in strawberry, apple, and mango (Kazemi, 2013; Ngullie et al., 2014; Shaaban et al., 2011) and stimulates production of the plant growth-regulating hormone indole-3-acetic acid (IAA) (Pasternak et al., 2019). It would be interesting to evaluate whether SA- or IAA-response genes are involved in the mechanisms of glucans on CMV infection in chili pepper plants. To the best of our knowledge, we are the first to report that $\beta$-glucans from $A$. pullulans inhibits $C M V$ infection and promotes plant growth and the yield of pepper fruit.

\section{Conflicts of Interest}

No potential conflict of interest relevant to this article was reported.

\section{Acknowledgments}

This work was supported by a grant from the Basic Research Program (PJ012426) of National Institute of Horticultural and Herbal Science, Rural Development Administration, Wanju, 55365, Republic of Korea. The English in this document has been checked by at least two professional editors, both native speakers of English. For a certificate, please see: http://www. textcheck.com/certificate/TXYhmm

\section{References}

Albersheim, P. and Valent, B. S. 1978. Host-pathogen interactions in plants: plants, when exposed to oligosaccharides of fungal origin, defend themselves by accumulating antibiotics. J. Cell Biol. 78: 627-643.

Ayers, A. R., Ebel, J., Valent, B. and Albersheim, P. 1976. Host-pathogen interactions: $X$. Fractionation and biological activity of an elicitor isolated from the mycelial walls of Phytophthora megasperma var. sojae. Plant Physiol. 57: 760-765.

Aziz, A., Poinssot, B., Daire, X., Adrian, M., Bézier, A., Lambert, B. et al. 2003. Laminarin elicits defense responses in grapevine and induces protection against Botrytis cinerea and Plasmopara viti- 
cola. Mol. Plant Microbe Interact. 16: 1118-1128.

Canto, T., Prior, D. A., Hellwald, K. H., Oparka, K. J. and Palukaitis, P. 1997. Characterization of cucumber mosaic virus. IV. Movement protein and coat protein are both essential for cell-to-cell movement of cucumber mosaic virus. Virology 237: 237-248.

Caranta, C. and Palloix, A. 1996. Both common and specific genetic factors are involved in polygenic resistance of pepper to several potyviruses. Theor. Appl. Genet. 92: 15-20.

Caranta, C., Pflieger, S., Lefebvre, V., Daubèze, A. M., Thabuis, A. and Palloix, A. 2002. QTLs involved in the restriction of Cucumber mosaic virus (CMV) long-distance movement in pepper. Theor. Appl. Genet. 104: 586-591.

Cho, J. D., Kim, J. S., Lee, S. H., Choi, G. S. and Chung, B. N. 2007. Viruses and symptoms on peppers, and their infection types in Korea. Res. Plant Dis. 13: 75-81. (In Korean)

Choi, G. S., Kim, J. H., Lee, D. H., Kim, J. S. and Ryu, K. H. 2005. Occurrence and distribution of viruses infecting pepper in Korea. Plant Pathol. J. 21: 258-261. (In Korean)

Choi, G.-S., Kwon, S.-J., Choi, S.-K., Cho, I.-S. and Yoon, J.-Y. 2015. Characteristics of cucumber mosaic virus-GTN and resistance evaluation of chili pepper cultivars to two cucumber mosaic virus isolates. Res. Plant Dis. 21: 99-102. (In Korean)

Choi, H. K., Song, G. C., Yi, H.-S. and Ryu, C.-M. 2014. Field evaluation of the bacterial volatile derivative 3-pentanol in priming for induced resistance in pepper. J. Chem. Ecol. 40: 882-892.

Choi, S., Lee, J.-H., Kang, W.-H., Kim, J., Huy, H. N., Park, S.-W. et al. 2018. Identification of cucumber mosaic resistance 2 (cmr2) that confers resistance to a new cucumber mosaic virus isolate P1 (CMV-P1) in pepper (Capsicum spp.). Front. Plant Sci. 9: 1106.

Doolittle, S. P. 1916. A new infectious mosaic disease of cucumber. Phytopathology 6: 145-147.

Ebel, J., Ayers, A. R. and Albersheim, P. 1976. Host-pathogen interactions: XII. Response of suspension-cultured soybean cells to the elicitor isolated from Phytophthora megasperma var. sojae, a fungal pathogen of soybeans. Plant Physiol. 57: 775-779.

Fereres, A. and Perry, K. L. 2019. Movement between plants: Horizontal transmission. In: Cucumber Mosaic Virus, eds. by P. Palukaitis and F. García-Arenal, pp. 173-184. The American Phytopathological Society, St. Paul, MN, USA.

Fesel, P. H. and Zuccaro, A. 2016. $\beta$-glucan: crucial component of the fungal cell wall and elusive MAMP in plants. Fugal Genet. Biol. 90: 53-60.

Gilbert, W. W. 1916. Cucumber mosaic disease. Phytopathology 6: 143-144.

Giner, A., Pascual, L., Bourgeois, M., Gyetvai, G., Rios, P., Picó, B. et al. 2017. A mutation in the melon Vacuolar Protein Sorting 41 prevents systemic infection of cucumber mosaic virus. Sci. Rep. 7: 10471.

Grube, R. C., Zhang, Y., Murphy, J. F., Loaiza-Figueroa, F., Lackney, V. K., Provvidenti, R. et al. 2000. New source of resistance to cucumber mosaic virus in Capsicum frutescens. Plant Dis. 84: 885-891.

Habili, N. and Francki, R. I. B. 1974. Comparative studies on tomato aspermy and cucumber mosaic viruses. II. Virus stability. Virology 60: 29-36.

Hayes, R. J. and Buck, K. W. 1990. Complete replication of a eukaryotic virus RNA in vitro by a purified RNA-dependent RNA polymerase. Cell 63: 363-368.

Heil, M. and Baldwin, I. T. 2002. Fitness costs of induced resistance: emerging experimental support for a slippery concept. Trends Plant Sci. 7: 61-67.

Jagger, I. C. 1916. Experiments with the cucumber mosaic disease. Phytopathology 6: 148-151.

Kang, W.-H., Hoang, N. H., Yang, H.-B., Kwon, J.-K., Jo, S.-H., Seo, J.-K. et al. 2010. Molecular mapping and characterization of a single dominant gene controlling CMV resistance in peppers (Capsicum annuum L.). Theor. Appl. Genet. 120: 1587-1596.

Kaplan, I. B., Gal-On, A. and Palukaitis, P. 1997. Characterization of cucumber mosaic virus: III. Localization of sequences in the movement protein controlling systemic infection in cucurbits. Virology 230: 343-349.

Kazemi, M. 2013. Foliar application of salicylic acid and calcium on yield, yield component and chemical properties of strawberry. Bull. Environ. Pharmacol. Life Sci. 2: 19-23.

Klarzynski, O., Plesse, B., Joubert, J.-M., Yvin, J.-C., Kopp, M., Kloareg, B. et al. 2000. Linear $\beta-1,3$ glucans are elicitors of defense responses in tobacco. Plant Physiol. 124: 1027-1038.

Kopp, M., Rouster, J., Fritig, B., Darvill, A. and Albersheim, P. 1989. Host-pathogen interactions. Plant Physiol. 90: 208-216.

Kwon S.-J., Cho I.-S., Yoon J.-Y. and Chung, B.-N. 2018. Incidence and occurrence pattern of viruses on peppers growing in fields in Korea. Res. Plant Dis. 24: 66-74.

Lapidot, M., Paran, I., Ben-Joseph, R., Ben-Harush, S., Pilowsky, M., Cohen, S. et al. 1997. Tolerance to cucumber mosaic virus in pepper: development of advanced breeding lines and evaluation of virus level. Plant Dis. 81: 185-188.

Lee, G. H. and Ryu, C.-M. 2016. Spraying of leaf-colonizing Bacillus amyloliquefaciens protects pepper from cucumber mosaic virus. Plant Dis. 100: 2099-2105.

Lee, J. H., Hong, J. S., Ju, H.-J. and Park, D. H. 2015. Occurrence of viral diseases in field-cultivated pepper in Korea from 2006 to 2010. Korean J. Org. Agric. 23: 123-131. (In Korean)

Lee, M. Y., Lee, J. H., Ahn, H. I., Yoon, J. Y., Her, N. H., Choi, J. K. et al. 2006. Identification and sequence analysis of RNA3 of a resistance-breaking cucumber mosaic virus isolate on Capsicum annuum. Plant Pathol. J. 22: 265-270.

Ménard, R., Alban, S., de Ruffray, P., Jamois, F., Franz, G., Fritig, B. et al. 2004. $\beta-1,3$ glucan sulfate, but not $\beta-1,3$ glucan, induces the salicylic acid signaling pathway in tobacco and Arabidopsis. Plant Cell 16: 3020-3032.

Ménard, R., de Ruffray, P., Fritig, B., Yvin, J.-C. and Kauffmann, S. 2005. Defense and resistance-inducing activities in tobacco of the sulfated $\beta-1,3$ glucan PS3 and its synergistic activities with the unsulfated molecule. Plant Cell Physiol. 46: 1964-1972.

Muramatsu, D., Okabe, M., Takaoka, A., Kida, H. and Iwai, A. 2017. 
Aureobasidium pullulans produced $\beta$-glucan is effective to enhance Kurosengoku soybean extract induced thrombospondin-1 expression. Sci. Rep. 7: 2831.

Ngullie, C. R., Tank, R. V. and Bhanderi, D. R. 2014. Effect of salicylic acid and humic acid on flowering, fruiting, yield and quality of mango (Mangifera indica L.) cv. KESAR. Adv. Res. J. Crop Improv. 5: 136-139.

Pasternak, T., Groot, E. P., Kazantsev, F. V., Teale, W., Omelyanchuk, N., Kovrizhnykh, V. et al. 2019. Salicylic acid affects root meristem patterning via auxin distribution in a concentration-dependent manner. Plant Physiol. 180: 1725-1739.

Peden, K. W. C. and Symons, R. H. 1973. Cucumber mosaic virus contains a functionally divided genome. Virology 53: 487-492.

Reunov, A. V., Lapshina, L. A., Nagorskaya, V. P. and Elyakova, L. A. 1996. Effect of 1,3;1,6- $\beta$-D-glucan on infection of detached tobacco leaves with tobacco mosaic virus. J. Phytopathol. 144: 247-249.

Scholthof, K.-B. G., Adkins, S., Czosnek, H., Palukaitis, P., Jacquot, E., Hohn, T. et al. 2011. Top 10 plant viruses in molecular plant pathology. Mol. Plant Pathol. 12: 938-954.

Sekine, K.-T., Kawakami, S., Hase, S., Kubota, M., Ichinose, Y., Shah, J. et al. 2008. High level expression of a virus resistance gene, $R C Y$ 1, confers extreme resistance to cucumber mosaic virus in Arabidopsis thaliana. Mol. Plant-Microbe Interact. 21: 1398-1407.

Seo, Y.-S., Rojas, M. R., Lee, J.-Y., Lee, S.-W., Jeon, J.-S., Ronald, P. et al. 2006. A viral resistance gene from common bean functions across plant families and is up-regulated in a non-virus-specific manner. Proc. Natl. Acad. Sci. U. S. A. 103: 11856-11861.

Shaaban, M. M., Abd El-Aal, A. M. K. and Ahmed, F. F. 2011. Insight into the effect of salicylic acid on apple trees growing under sandy saline soil. Res. J. Agric. Biol. Sci. 7: 150-156.
Sharp, J. K., McNeil, M. and Albersheim, P. 1984a. The primary structures of one elicitor-active and seven elicitor-inactive hexa(beta-D-glucopyranosyl)-D-glucitols isolated from the mycelial walls of Phytophthora megasperma f. sp. glycinea. J. Biol. Chem. 259: 11321-11336.

Sharp, J. K., Valent, B. and Albersheim, P. 1984b. Purification and partial characterization of a beta-glucan fragment that elicits phytoalexin accumulation in soybean. J. Biol. Chem. 259: 1131211320.

Song, G. C., Choi, H. K. and Ryu, C.-M. 2013. The folate precursor para-aminobenzoic acid elicits induced resistance against cucumber mosaic virus and Xanthomonas axonopodis. Ann. Bot. 111: 925-934.

Statistics Korea. 2019. Production of chili pepper, sesame and highland potatoes in 2019. URL http://kostat.go.kr/ [cited 10 January 2021].

Suzuki, K., Kuroda, T., Miura, Y. and Murai, J. 2003. Screening and field trials of virus resistant sources in Capsicum spp. Plant Dis. 87: 779-783.

Takahashi, H., Miller, J., Nozaki, Y., Takeda, M., Shah, J., Hase, S. et al. 2002. RCY 1, an Arabidopsis thaliana RPP8/HRT family resistance gene, conferring resistance to cucumber mosaic virus requires salicylic acid, ethylene and a novel signal transduction mechanism. Plant J. 32: 655-667.

Yoon, J.-Y., Choi, S.-K., Palukaitis, P. and Gray, S. M. 2011. Agrobacterium-mediated infection of whole plants by yellow dwarf viruses. Virus Res. 160: 428-434.

Yoon, J. Y., Paluakaitis, P. and Choi, S. K. 2019. Host range. In: Cucumber Mosaic Cirus, eds. by P. Palukaitis and F. García-Arenal, pp. 15-18. The American Phytopathological Society, St. Paul, MN, USA. 